\title{
REPRESENTATIONS OF REFUGEES AND LOCAL PEOPLE IN GREEK POETRY DURING THE EUROPEAN MIGRANT CRISIS
}

\author{
Christina Linardaki \\ Researcher, \\ Advanced Media Institute, \\ Nicosia, Cyprus
}

\begin{abstract}
:
This paper looks into Greek poetry written, in its bulk, during the years of the European migrant crisis (2014-2018) for ways in which refugees and locals are presented. The poems are analyzed in the framework of critical discourse analysis (CDA) in terms of the social language, situated meanings, intertextuality, figured worlds and discourses they contain (Gee, 2011). Greek poets see in refugees a heroic part of humanity and a manifestation of the human struggle and will to live; thus, they are sanctifying them, presenting them as martyrs. Moreover, Greek poets see locals and Westerners as insensitive villains who are after their eradication. This is obviously a distorted and hyperbolic point of view, which however may hide true aspects of reality in its exaggeration.
\end{abstract}

Keywords: refugees, European migrant crisis, Greece, poetry, CDA

\section{Introduction}

The European migrant crisis, i.e. the crisis characterized by large numbers of people flooding the European Union from across the Mediterranean Sea or overland through Southeast Europe has been acutely affecting Greece, one of the main countries of their entrance into the EU. ${ }^{\text {ii }}$ Literary texts, among them poems, could offer an insight into the attitudes of Greek people towards migrants and themselves, as they can "function as assertions that claim to be true about the world and [...] thereby relate the fictional narrative to the factual and moral world of actual experience". ${ }^{\text {iii }}$

The arrival of around 900,000 refugees $^{\text {iv }}$ in the period of heightened migrant flows (20132015), on account of the war in Syria and other conflicts (in Iran, Iraq, Afghanistan etc.), helped to highlight the consequences of the European migration policy on the lives of hundreds of refugees who found themselves in Aegean waters. Their best chance to enter European ground

\footnotetext{
i Correspondence: email cleareaching@gmail.com

ii See https://www.ecfr.eu/specials/mapping migration\# (accessed on 17.3.2019).

iii See entry "Fiction and Truth" in Abrams, M.H. (1957/1999).

iv See Petracou et al. (2018), p. 13; also https://www.asylumineurope.org/reports/country/greece/statistics and https://data2.unhcr.org/en/situations/mediterranean/location/5179 (accessed on 16.3.2020).
} 
was to travel in precarious inflatable boats from the coasts of Turkey to the Greek islands of the Aegean. Notwithstanding that, they traveled with any imaginable means available, paying illegal traffickers and legal transporters (bus and taxi drivers) to help them cross the Greek state and reach different destinations in Europe, for as long as the borders were open. Once the roads to Europe were closed, about 60,000 refugees were trapped in Greece. On the one hand, the solidarity that the inhabitants of the islands showed the exhausted people was formidable and brought emotional comfort to all Greeks who could not be there to help. On the other hand, fear gave rise to a xenophobic wave that lasts even today; the xenophobic wave included atrocities, like shouting at them "go back"v or forcing their boats away ${ }^{\mathrm{vi}}$ or preventing them from going to the shelters or housing that the Greek state provided ${ }^{\text {vii,viii }}$ or looting such shelters before they arrived $^{\mathrm{ix}}$.

The perception of refugees as hostile intruders and not as carriers of inviolable rights according to international law was not acceptable by the formal Greek state in the years of the refugee crisis; the fact that voices to this direction existed and still exist, however, probably expresses the bewilderment of the politicians involved. The issue of social protection of refugees and of those seeking asylum remains central in discussions to this day. Their equal treatment and their integration into society have not advanced significantly at the institutional level and pertinent questions remain.

Since real life spills over into art, it is interesting to see how not only immigrants, but also the Greek society have been presented in the poetic examples that were collected, since they may reflect feelings and stances of real-life people involved.

\section{The sample}

Forty-seven poetry collections that contain poems about immigrants or are dedicated to them in full (more than 170 poems in total) were examined. ${ }^{x}$ However, only 85 poems form the convenience sample that was deemed appropriate for the analysis in this paper. In more detail, there were three (out of the 47) poetry collections fully dedicated to refugees: (i) Frossoula Kolosiatou (2017), (ii) Zafeiris Nikitas (2015), (iii) Christos Toumanidis (2014). Out of these three collections, there were selected only ten poems from Kolosiatou's, nine poems from Toumanidis's and just one poem from Nikitas's, because the latter collection spoke generally about refugees and was largely irrelevant to the refugee crisis. The selection was considered

\footnotetext{
v https://www.youtube.com/watch?v=2BadznLzhbs (accessed on 15.7.2020).

vi https://www.youtube.com/watch?v=FEYA6yqkJrI (accessed on 13.8.2020).

vii See, for example, https://www.infomigrants.net/en/post/24586/greece-locals-set-fire-to-hotel-for-asylum-seekers (accessed on 15.7.2020).

viii https://abcnews.go.com/International/wireStory/greece-locals-stop-migrants-camps-reaching-housing-70533257

ix https://www.dailysabah.com/politics/greek-locals-hostility-against-migrants-threatens-safety/news (accessed on 15.7.2020).

x I cordially thank, for their help in locating the poems, the literary bloggers Dimos Chloptsioudis (tovivlio.net), Dione Dimitriadou (meanoihtavivlia.blogspot.gr) and Katerina Tsitsekli (stigmalogou.blogspot.gr), as well as Mandragoras and Vakxikon publications.
} 
necessary, as a larger volume of poems would perhaps distort the results: each poet finds particular symbols more accommodating than others and prefers them; thus, a larger number of poems from a specific collection would yield a greater number of similar results.

More than one poem may have been selected from the same collection, however, even if this collection was not fully dedicated to refugees. They have been selected because they reveal different aspects of the subject in question. Here follows a list with all the poems used in the analysis:

1. "Refugees" (from Siotis, 2004)

2. "Refugees" (Chouliaras, 2005)

3. "Immigrant" (Skouroliakou, 2008)

4. "Lynch from Rwanda" (ibid.)

5. "The sickness" (Koutsoumbeli, 2009)

6. "Migrants of sorrow" (Chatzopoulos, 2012)

7. [My poetry is full of refugees] (Xirogianni, 2013)

8. "Migratory" (Naoum, 2013)

9. "Global nation" (Stamboglis, 2014)

10. "Reportage II" (ibid.)

11. "My tenants II" (ibid.)

12. "Homeland opportunities" (ibid.)

13. "Migrant lark on the ground" (Dimitriadou-Efraimidou, 2014)

14. "Migratory birds" (Sifiltzoglou, 2014)

15. "Migrants" (Kaimaklioti, 2014)

16. "Only the silence of man" (Kolosiatou, 2014)

17. "Talking statues" (Toumanidis, 2014)

18. "Beseechers arrived" (ibid.)

19. "Everywhere for them the roads are closed" (ibid.)

20. "Through their broken glass" (ibid.)

21. "News'" (ibid.)

22. "We guarded ourselves" (ibid.)

23. "What the refugees said" (ibid.)

24. "Where are we going, where are they taking us" (ibid.)

25. "If we survive" (ibid.)

26. “Tonight I feel shame" (Konstantopoulou, 2014)

27. "Children of war" (Vakirli, 2015)

28. "Amygdaleza 2012" (Dimouli, 2015)

29. "Memory of returning" (ibid.)

30. "Fiesta" (ibid.)

31. "Hope" (ibid.)

32. "Poisonous island" (ibid.)

33. "Armies of teenagers and children went aboard the boat" (op.cit.)

34. "Sewol shipwreck" (Nikitas, 2015) 
35. "Bulletin of incidents" (Skouroliakou, 2015)

36. "Purgatory" (Sakalis, 2015)

37. "Winter wave" (Lountzis, 2015)

38. "Away" (Verouchis, 2015)

39. "Poetry shipwrecked" (Chloptsioudis, 2016)

40. "Mother from Syria" (ibid.)

41. "Wet grave" (ibid.)

42. "From Aegean" (ibid.)

43. "On Christmas day" (Sidira, 2016)

44. "Birds of the East" (Papadopoulos, 2016)

45. "The little girls" (Koutsoumbeli, 2016)

46. "The messmates of another land" (ibid.)

47. "Days of marching" (Andrikopoulou, 2016)

48. "The road" (ibid.)

49. "They are all the same" (Latsari, 2016)

50. "A bag of home and homeland I became" (Kaitatzi-Choulioumi, 2017)

51. "Refugees - Lullaby" (ibid.)

52. "Refugees" (ibid.)

53. "What we loved most" (ibid.)

54. "Some water" (ibid.)

55. "Migrants 2016 AD" (Tetrazis, 2017)

56. "The absurdity of migration" (Liatzoura, 2017)

57. "Stealing from the dead" (ibid.)

58. "News bulletin" (ibid.)

59. "Ritsona camp" (ibid.)

60. "Eidomeni" (ibid.)

61. "The refugee of the Aegean" (ibid.)

62. "Without remorse" (Karakokkinos, 2017)

63. "Typhoons" (ibid.)

64. "Amok" (Ganelis, 2017)

65. "The shipwreck" (ibid.)

66. "The last moon of spring" (Kolossiatou, 2017)

67. "The medusa" (ibid.)

68. "With hands stressed out" (ibid.)

69. "Calamity" (ibid.)

70. "Rest of life" (ibid.)

71. "Voices" (ibid.)

72. "Images" (ibid.)

73. "Desperate" (ibid.)

74. "The furthest away the most dangerous" (ibid.)

75. "Without a talisman" (ibid.) 
76. "Refugee camp" (Mendrinou, 2018)

77. "Renouncement of lines" (Frangos, 2018)

78. "Dead refugee children" (ibid.)

79. "Santa Claus and the refugee child" (Kopsida-Vrettou, 2018)

80. "A place in Heaven" (ibid.)

81. "Sea cemetery" (Politou, 2018)

82. "Alms" (ibid.)

83. "Beseechers" (Fillis, 2018)

84. "Antigone's diary" (Aggelopoulos, 2018)

85. "Out of place" (Chatzicharalambous, 2018)

It is evident that the bulk of these poems span from 2014 to 2018 . This is not to exclude poems written prior to 2014: Greece has been the point of entry to the EU for refugees from different parts of Asia and Africa long before the current European migration crisis. Thus, poems that were written prior to the refugee crisis may resonate very well with its circumstances. As a result, the start of the period that poetry in the sample actually covers is 2004.

However, poetic voices speaking about refugees have grown much denser with time. In the sample, for example, the yearly average of collections containing poems on the subject between 2004 and 2013 was only one collection; however, from 2014 onwards the average was 7.6, with pertinent collections escalating as shown in Chart 1, in tandem with the escalation of the refugee crisis.

Chart 1: Number of poetry collections dealing with refugees (2004-2018)

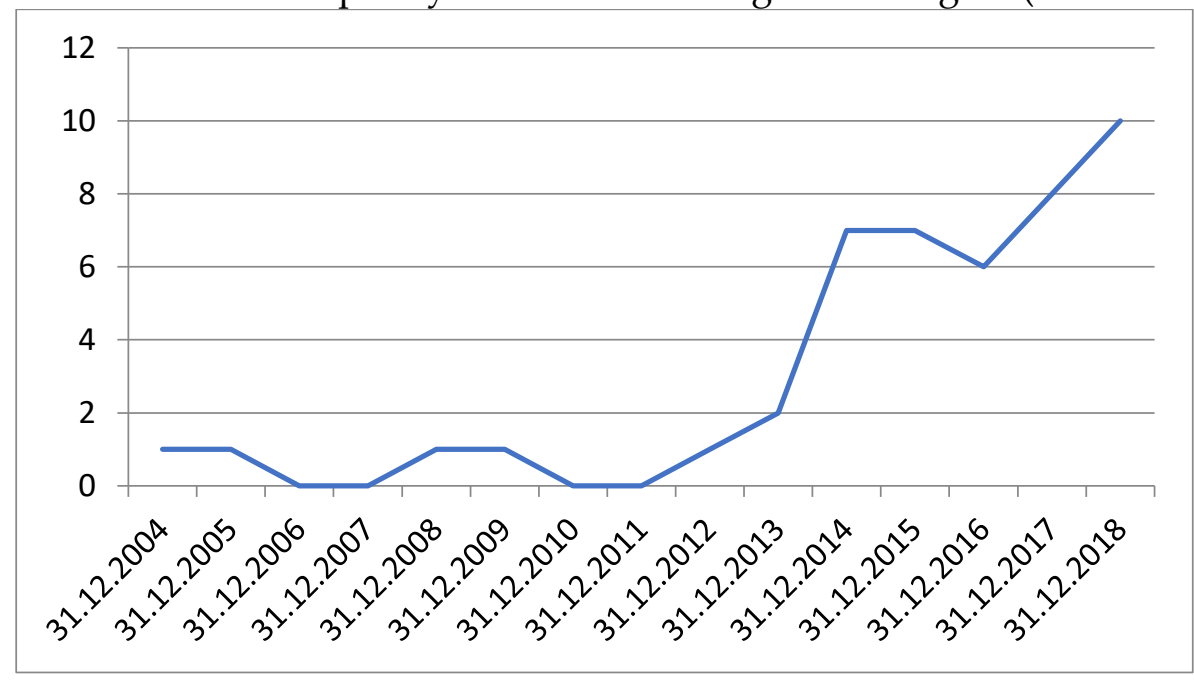

This shows that, as the refugee influx was intensifying, reality was spilling over to art more intensely and art was responding in return, trying to provide explanations for what was happening in reality or just to picture it. 


\section{Methodology}

Trying to analyze speech in order to arrive at between-the-lines meanings is not an easy task on its own. But trying to analyze literary speech in general, and poetic speech predominantly, is even harder, because a further layer is added to common talk: that of fiction. Literature may be based on real facts but by definition involves fictional accounts. There is always an author (in this case, a poet) describing "the facts", which however are not "the facts" but rather his take on them. Moreover, poetry is elliptical and what is implied is more than what is actually told. It is a genre in which the poetic function, referred to in Jakobson's linguistic model, ${ }^{\text {xi }}$ is dominant. As a result, the language is more opaque and emphasis on the signifier and the medium, or the form, style and code takes on different weight. According to Oxford Reference, ${ }^{x i i}$ poems undermine any sense of "natural" or transparent connection between a signifier and a referent.

Without losing the quicksand of poetry from mind, I looked for analytical tools for the above poems in critical discourse analysis (CDA). CDA focuses, inter alia, on the relations of "power, dominance and inequality and the ways these are reproduced or resisted by social group members through text and talk". xiii CDA has been implemented along a number of approaches, the most notable ones being the discourse-historical approach (Wodak \& Meyer, 2001), the socio-semiotic approach (Fairclough 1989, 1992, 2010) and the socio-cognitive approach (van Dijk, 1995, 2001, 2014, 2015). For the purposes of this paper, however, I have looked for the appropriate analytical tools of poems in Gee (1999, 2004, 2011).

Gee proposes five tools "about how language ties to the world and to culture" (2011:150) which can be used when performing CDA: situated meaning, social language, intertextuality, figured worlds and Discourse (2011:150ff). Situated meaning, derived from cognitive psychology, is the specific meaning situated in the context of a word's use; in this way, a word, a phrase or an utterance acts as a clue or cue that guides active construction of meaning in context. This can happen because words, phrases and utterances can take up more meanings than their general one; any structure in language has a certain "meaning potential", i.e. a range of possible meanings that it can take on in different contexts. Social language, derived as a notion from sociolinguistics, is a way of using language (choice of words, intonation, style etc.) to enact a particular socially situated identity. Examples of social language are the language of medicine, literature, street gangs, sociology, law, rap etc. Each of these languages has its own lexical and grammatical resources, which are combined to enact specific social identities. Since however, in this paper, it is social language that gives words their situated meanings and the latter is explored within the social language, a reversal has taken place: social language is examined first and situated meaning second.

\footnotetext{
xi Jakobson, R. (1960), “Closing Statement: Linguistics and Poetics” in Sebeok, T. A. (ed.), Style in Language, New York: Wiley, 350-377.

xii See "Poetic function" in https://www.oxfordreference.com/view/10.1093/oi/authority.20110803100333199 (accessed on 7.12.2020).

xiii van Dijk, T. A. (1995), 18.
} 
Intertextuality, which was derived from literary criticism, involves quotation, reference or allusion of one text to another one, or reference to another social language, associated with a different identity, within the same context. This may include direct quotations or allusions to what hearers/readers realize is taken from another source. Or it may be about a different style of language (a different social language) incorporated in the main one. The notion can be expanded to cover references or allusions to media (TV, the Press, film, video games etc.), which can be seen and treated as "texts" too.

The situated meanings of words and phrases within given social languages plus intertextuality trigger specific figured worlds (a notion derived from psychological anthropology), i.e. everyday theories (narratives, images, schemas, metaphors and models) about the world that tell people what is typical or normal. We use the words we use based on their typical usage, unless something in the context makes us think that the situation is not typical. But typical pictures are necessary in communication, because they allow us to go on without having to think about everything all the time. They are something like cognitive shortcuts to meaning. And of course they may vary across social or culture groups in such a way that something that is typical for, say, a European Christian family may not be that typical for a Syrian Muslim one. Thus, a figured world is a picture of a simplified world that captures what is taken to be typical or normal, and its challenges.

Finally, Discourse is a manifestation of how meaning goes well beyond human language to involve objects, tools, technologies etc. used in enacting a specific identity. Discourse as a notion is derived from a variety of areas (cultural anthropology, cultural psychology, sociolinguistics and psychology). It involves all the conventions that people use when they talk and act not just as individuals, but as members of various social and cultural groups. Discourse is about being "kinds of people". It allows a focus on the fact that, when people mean things to each other, they have to communicate who they are and what they are doing, in terms of what socially situated activity they are seeking to carry out.

\section{The analysis}

\subsection{Social language}

Social language in the poems is of course poetic language: poets speak out their feelings and views about the situation with refugees. Contrary to everyday talk, poetic language is laden with figures of speech, such as metaphors, similes, hyperboles, irony, oxymorons, alliterations, personifications, etc. Other such elements are patterns of sound that are produced from the alternation of short and long syllables, metric considerations and unusual patterns in word ordering. Since I am not considering a narrow number of poems, but 85 in this paper, I have paid attention to figures of speech only, especially those that contribute to the representations of concern. Here are some striking examples of such language:

In poem Nr. 3, a migrant is seen buying a small piece of sun with a "living card" of nonspecific location. This metaphor points to Greece (a sunny country most of the year) in which a migrant has no specific living circumstances. 
In poem Nr. 5, ghost boats with refugees are seen traversing time and constantly hitting icebergs.

Poem Nr. 9 ends with the image of a change of continents (instead of a change of clothes) in the plastic bag that a refugee is holding.

Poem Nr. 13 is an extended metaphor about a refugee who is presented as a bird. The bird has migrated to another land where it can barely find any food. "Had it known", the poem ends, that it would migrate and change its habits, that its winds would go atrophic in a treeless world, and all that for a little worm he has managed to find, "it would wish it weren't born a bird".

In poem Nr. 35, it is not temperature but shame that is hitting high degrees.

In poem Nr. 40, a Syrian mother pushes the boat with her children in it away, and puts a small piece of horror with them so that they remember how terrifying home was and never come back.

In poem Nr. 41, the rain is seen as a rain of nails that crucifies dreams, as justice is an underage refugee without a raincoat sitting inside an inflatable boat with holes.

Poem Nr. 60, entitled "Eidomeni", after the name of an infamous Greek refugee camp where hundreds of people were piled up under unhealthy conditions, is an ironic statement about the journey of refugees seen in the context of "refugee tourism", promising a unique experience that will not be forgotten, even by their offsprings, offered at the bargain price of a third soul given as a present for every other two.

A humongous shadow comes out of the sea in Poem 69, leaving behind it a "homeless despair" (reference to the homelessness of refugees).

In poem Nr. 85, a refugee is talking to his grandfather telling him that the magic carpets they used to weave back home have turned into ashes.

\subsection{Situated meanings}

As already pointed out, it is social language that gives words their situated meanings, their usage changing in unexpected ways within the figures of speech employed. Thus, situated meaning is explored within these figures of speech. This allows symbols to be identified, as well as any added significance to certain words or phrases.

Since the sample is broad, a quantitative approach was adopted, enabling as it does the extraction of conclusions between all 85 poems in the corpus. More particularly, recurring words and/or clusters of words were counted arithmetically in each poem and the occurrences were recorded in an Excel file. It soon became evident that an occurrence of a word/meaning/symbol should be counted only the first time that it was found in a poem, so as to prevent more "popular" words from appearing at vast numbers, overshadowing less used words. Words that were counted include: Aegean/Mediterranean, boats, blood, children, concentration camps, death/dead, dreams, fire, food/bread, home, homeland, hope, migrants, migratory birds/migration, mother, night/darkness, pain, refugees, road, screams, sealopen sea/waves, shelter, shipwreck, sinking/drowning, sorrow, strangers, tears, water, wind. 
A threshold of at least 10 total one-time occurrences was established and Chart 2 was then produced, which sums up the findings, sorted from most to least. Only 18 of the above mentioned words managed to pass the threshold.

Chart 2: Number of one-time occurrences within the sample

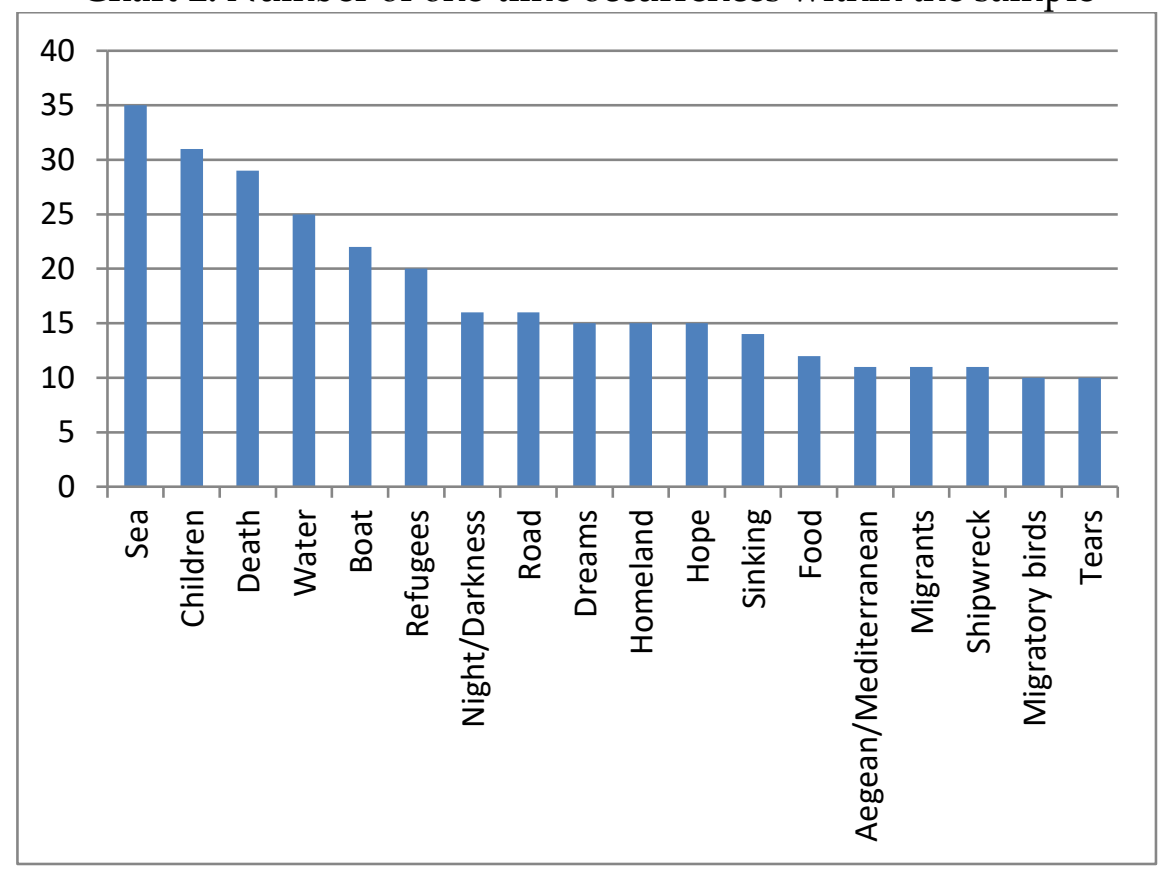

After identifying the most recurring words, I ventured to look them through the figures of speech in which they occur, in order to identify their situated meaning.

"Sea", a cluster of words that also includes salty water, open sea, waves, blue waters etc., refers to the sea that we all know, which however takes on different situated meaning. Thus, it becomes "bitter" in poem Nr. 26, where the poet speaks of the shame that she feels. In poem Nr. 34 , sea is seen in a personification embracing her beloved children but only because they are drowned. In poem Nr. 43 the sea is seen washing ashore corpses of little children inside the poet's room. In poem Nr. 72, we see a sea of souls (which alludes to the fact of the people drowning in the sea but also the fact of their great numbers) and also a sea cut in two, as with Moses and the road to the Promised Land, only in this instance the sea-cut is not about saving lives or opening roads, it is about devouring refugees and ending their journeys. In poem Nr. 75, sea becomes a mirror of death for all those trying to cross it. In poem Nr. 81 the sea is seen full of crosses - the cross being a symbol of martyrdom in Greek orthodox culture - but is also seen becoming red (from blood) and black (from grief), while still remaining the same sea that has always been wetting the shore of the poet's birthplace.

"Aegean/Mediterranean" narrow down "sea", showing locality. In poem Nr. 35, the Mediterranean is seen vomiting migrants. In poem Nr. 42, the title reads "Sanctified Aegean", in irony, because in the poem the Aegean is actually seen as a place of death for both people and their hopes. In poem Nr. 61, the Aegean features on the title again, which now reads "The Aegean 
refugee" but, in the lines, the refugee is storing away his soul inside an Aegean coffin. Poem Nr. 78 sees the foam of sea waves becoming a shroud for little children in the Mediterranean waters. The means by which the sea or, more specifically, the Aegean/Mediterranean are crossed, i.e. "boats" (plain, inflatable or precarious/crooked), appear in 22 poems. In poem Nr. 29, refugees are seen inside boats without sail, i.e. boats without the possibility of being guided to a destination. In poem Nr. 61 hope is seen piled up along other things inside a boat. In poem Nr. 84 silence is a boat traversing the skies.

"Shipwreck" (11 occurrences) will be also discussed under Intertextuality, and "Children", seen in 31 poems, will be presented both under Intertextuality and under Cultural_models.

The word "food" (12 occurrences, including "bread") is first encountered in poem Nr. 6: "the day's bread, one loaf in half". In poem Nr. 29, the poet describes the condition of people inside a boat without a sail and also without drinking water or food or a mother's embrace. In both these instances, food serves as a metaphor for poverty or deprivation. In poem Nr. 48 , a mother is thinking of her child and is wondering if he is taking proper food at the camp. In poem Nr. 65, refugees are seen eating bread while waiting at the pier to flee. In both these instances, food/bread become a metaphor for survival.

"Homeland" (15 one-time occurrences) first appears in poem Nr. 18, where it is used literally to make the statement that refugees have taken the decision to live without a homeland. In poem Nr. 24, it is said that pain has no homeland or words. In poem Nr. 50, homeland becomes a bag carried by a refugee and in the next verse the refugee himself becomes his own homeland. In poem Nr. 62, refugees are looking for a new, warless homeland; can there be a new versus an old homeland? Only in the heart.

"Dreams" (15 occurrences) are seen crucified in poem Nr. 41 and dead in poem Nr. 44. In poem Nr. 66, they become expendable and in poem Nr. 71, they are smuggled. In poem Nr. 76, they are full of dead people and, in poem Nr. 77, they are wide and spacious, only to be crowded by dead bodies soon afterwards. In poem Nr. 80, personified Death is seen made of flesh and dreams. Children's dreams are azure in poem Nr. 89.

"Hope" also appears in 15 poems. In poem Nr. 40, a Syrian mother lets a smile loose from her hair to fly away with the wings of hope, while pushing the boat with her children away. In poem Nr. 42, hope is hiding inside sunken shells (i.e. has gone down to the bottom of the sea with the refugees carrying it). Poem Nr. 58 talks about sold-out homelands and hopes that have been bought; the poem ends with the line "hope has hunched its back" in a surprising personification, because if hope was human-like, it would certainly stand erect. In poem Nr. 55, barbed wires have drowned hope and in poem Nr. 60 hope has gone rotten. All these metaphors, personifications and images point to abandoned hopes or hopes that have been dashed.

"Night/darkness" (and also "obscurity/obscure") is seen in 16 poems. In poem Nr. 9, words brush the hair of a refugee at night. In poem Nr. 17, refugees are seen travelling from the darkness of the East to the ruins of the West. In poem Nr. 21, refugees themselves are likened to night. In poem Nr. 38 reference is made to dark waters where people get drowned. In poem Nr. 61 , the poetic subject is a refugee who says that he is afraid of the dark, while walking inside a "deadly darkness". In poem Nr. 67, night is a naked woman that tries to prevent the death of 
refugees, but in poem Nr. 69, night vibrates and cuts them to pieces. In poem Nr. 74, night is seen uttering the monologue of sorrow, while refugees are crawling in the dark. Wherever it is used conventionally (and it does so in many occurrences, e.g. in poem Nr. 18, which is about refugees arriving to Greece one night), the night is seen as an intense element that creates atmosphere or a powerful backdrop that can corroborate to or enhance the other messages in the poem.

"Death" (which also includes any reference to "dead", "corpses", "grave", "graveyard") ranks third in the number of total one-time occurrences, counting 29 of those. Death is bought off in poem Nr. 21 and in poem Nr. 35 hands are seen, exchanging dead banknotes. In poem Nr. 47 Death is an imaginary young lady lying on the coast. In poem Nr. 68, dead people are migrating and in poem Nr. 76 these dead people visit the speaker in his dreams. In poem Nr. 77, there is an underwater graveyard, and in poem Nr. 78, whole beaches have been turned into graveyards under a feeble moonlight that lights over them as a candle. In poem Nr. 80, Death is seen walking barefoot on the forehead of a child. Death is also referred to symbolically in the poems, to mark the end of a period or the end of a specific status.

"Sinking" (and "drowning") has 14 one-time occurrences. In poem Nr. 31, people are drowning noiselessly, like after a diver's last breath. In poem Nr. 42, we see wet shoes sinking into salt and leaking exile.

Mention to "refugees" and "migrants" is corroborated with mention to "migratory birds/migration". We will see these words again, under Figured Worlds.

"Road" (16 occurrences) is seen in poem Nr. 1 uncertain as to where it leads. In poem Nr. 4 , there are roads of wounds. In poem Nr. 55, the roads of imagination are the only ones that remain open. In poem Nr. 59, roads are showing solidarity as the people riding through them carry petty things like toilet papers and vegetables to a refugee camp - and that's all the help they provide. In poem Nr. 79, Santa Claus is seen talking to a refugee boy about the road leading to the Promised Land, the one that he shows all children of the world at Christmas time; only that the refugee boy is half-dead, his lips blue, the marrow sipped out of his bones by cold winter.

"Tears" (10 occurrences) in poem Nr. 52 are so many that make a seed grow. In poem Nr. 79 , tears escape children's dreams only to enter large clay jars and be stored in them, and in poem Nr. 85, a refugee is wondering what to do with his tears that he has been dragging along for many years as they never dry up.

Finally, non-salty "water" (25 occurrences) is seen in its literal sense, but is an element traditionally symbolic of emotions that intensifies all the figures of speech in which it occurs. It may also be seen providing a peaceful element that contrasts sharply with the harsh conditions of refugees, as in poem Nr. 51.

\subsection{Intertextuality}

Intertextuality is about quotes taken from other texts or about the reference or allusion of one text into another. It may also involve instances of another social language within the same context.

Children are considered vulnerable across cultures and hardship is magnified when they are involved, mainly because they are so helpless. They also constitute a powerful global symbol 
of innocence. The horrible image of little Ilan washed dead ashore that featured in the news and on the first pages of numerous newspapers literally haunted Greeks and certainly Greek poets: all references to children in the sample can be seen as echoing this sad fact. Thus, in poem Nr. 32, children appear to have sea weeds for hair and shells for eyes, apparently having drowned. In poem Nr. 51, children are lying "in the calmness of sea depths". In poem Nr. 67, a little child begs the waves to let him live but soon after he touches the bottom of the sea, which becomes red and smells of fear. In poem Nr. 77, a sailor jumps into sea and comes back out holding two breathless children in his hands. Poem Nr. 78 is entitled "Dead refugee children" and we already saw the image of sea foam turning into a shroud for children. In poem Nr. 81, children's hands are seen digging the water, looking for God. In poem Nr. 82, a child with a moon-like face lies on a deserted road, his tongue cut; but he is holding the world's pain between his teeth in the form of a gold coin. Unsettling news about boats, overloaded with refugees, sinking just outside the port in bad weather are all echoed in these lines.

Notwithstanding reference to children, poets are keen on using other elements of intertextuality as well. For example, some poems contain parentheses that reveal another voice commenting or speaking. Poem Nr. 28 talks about another infamous refugee camp, Amygdaleza. A mother is wondering if her child is eating properly at the camp; the parenthesis emphasizes that it is not a concentration camp "(as they say)"; this is a euphemism that only underlines the harsh conditions which are similar to a concentration camp's, like that of the Nazi. In poem Nr. 60, which we saw in Social Language, after enumerating the "glorious" attractions of the journey with "Migrant" travel agency, there is an "etc." followed by a parenthesis "(which are not mentioned here, for reasons of economy)" - but it is not economy of words, it is economy of History, as if History is leaving out its shameful pages on refugees.

Other poems contain spoken statements or dialogues. These elements serve to give the poem immediacy and add intensity, but also reveal different voices and different aspects. In poem Nr. 20, which is about the cruelty of the Westerners, the latter are given a voice: "What refugees and immigrants, they are just signs of the times that will pass...". Poem Nr. 21 shows the indifference and the annoyance of local people at the arrival of refugees: half of the population is wondering how did they get past the guardians of the borders and the other half is shouting at them, sending them back to their homelands. In poem Nr. 76, a survivor considers himself safe because he has got a mattress now, a blanket and a pair of borrowed shoes. In his dreams, however, he sees the people he had been travelling with, dead now, asking him "What are you doing over there? Why did you stay?". And then his mother (who is also dead) appears and pushes him back with the living.

Finally, certain poems contain rhetorical questions or phrases bearing an oral speech quality, uttered by the poetic subject or perhaps the poet him/herself. For example, poem Nr. 4 ends with the line "Please forgive me", which is the poet's/poetic subject's appeal to a refugee child. In poem Nr. 22, we see the question "[Pain's] hungry children, aren't they our own too?"; also, in poem Nr. 23, "[refugees are] a weather condition, a storm that will pass". Such questions or phrases do more than intensifying the general point of the poem. They are a direct address to the reader, constituting a voice that rings higher than the general voice in the poems. 


\subsection{Figured worlds}

Figured worlds are a reflection of everyday theories (narratives, images, schemas, metaphors and models) about the world that inform people about what is typical or normal. Children could be such a schema. But, in the poems of the sample, refugees' children are juxtaposed to "our children" in an interesting divide. This divide, "their children" versus "our children", challenges the universal schema. The challenge is aptly used to underline the different circumstances, if not realities, pertaining to each group of children. Thus, in poem Nr. 22, we don't see refugee children, but Greek children in their homes. It is for their sake that the Greeks are shutting out of their homes migrant pain and trouble. Poem Nr. 27 is entitled "Children of war" and talks about children's voices that have become screams of pain or death. It also contains an image of a child's shirt with a bullet hole in it, while also talking about the slaughtering of children in a Syrian school. In this poem too the division between "their children" and "our children" is underlined: "their children's" hands are dyed in blood, "ours" are holding rose petals. In poem Nr. 35, children's playgrounds become death-bearing omens for "their children". In poem Nr. 46 children's toys include drowned bunnies and torn cuddle bears, along with a music box playing an out-of-rhythm lullaby. Happy symbols are seen wrecked, as a testimony of the hardship "their children" are going through. We see, therefore, symbols of serenity connected with "our children", whereas "their children" are presented inside horrific circumstances.

There are, however, certain poems where an interesting mix of the two groups occurs. In poem Nr. 38, for example, "our children" are having a nice bath in the bathtub playing with their plastic boats that sink, while "their children" are inside real sinking boats; at the end of the poem, as the water in the bathtub is getting cold, our children embrace one another happy that they made it again, they got rescued from the shipwreck and the cold. This is a clever fusion that, even if fostering a division between the two, manages to merge the two groups and actively put the second one ("our children") in the place of the first one ("theirs"). This is also the case in poem Nr. 43: it is Christmas time and the poet's grandson is under the Christmas tree asking for his gift, while his grandmother (the poet) sees in the room refugee children drowning, in another successful mix of the two realities. Poem Nr. 49 also marks the difference between "our children" and "theirs", presenting different scenes from their lives (obviously ours' is happy and theirs' is horrible), but ends with the line "All children are the same" in a deeply ironic statement. Poem Nr. 79 is entitled "Santa Claus and the refugee child". Santa has been fishing the refugee child out of the sea every single night, eventually taking him in his sleigh; then, they look together at sins and shipwrecks from high above. The refugee child will become Santa's assistant and together they will place presents in other refugee children's freezing hands or they will wipe the tar off their azure dreams.

Another notion that is challenged is that of "peace". In poem Nr. 10, "peace" is seen to mean something alien to its nature, "an extraordinary condition above the facts", i.e. unplugged from reality; godly feelings only help to nurture "the ethics of fear". This is also the case with "sorrow". Sorrow is being bought at a bargain price through the images of distressed children in poem Nr. 62, only to be sold as cheap, empty rhetoric about truth and justice. 
And a quantitative input. Mention to "refugees" (20 one-time occurrences) and "migrants" (11 occurrences) is quite dense and is emphasized further with mention to "migratory birds/migration" (10 occurrences). The difference in the number of occurrences is big, with "refugees" occurring almost twice as much as "migrants" and twice as much as "migratory birds". This is because "migrants" and "refugees" are not synonyms. There are migrants even in times of peace: they change location in search of a better life, even if nothing tragic is happening to their homelands. Refugees however are a different story: they flee from their homelands because they are in grave danger and are trying to survive. Migratory birds cannot be seen as refugees, but connote to human populations migrating which has been happening throughout history. Migratory birds add a naïve, poetic tone to the management of the notion. At the same time, the word "refugees" gives a tragic note.

\subsection{Discourses}

Discourses sum up all the previous elements, thus they show the poets' position relevant to refugees. From what we have already seen, we understand that Greek poets see in refugees a heroic part of humanity and a manifestation of the human struggle and will to live; thus, they are sanctifying them, presenting them as martyrs. Greek poets completely sympathize with them and see locals and Westerners as villains who are after their eradication. This is obviously a distorted and hyperbolic point of view, which however may hide true aspects of reality in its exaggeration.

Poems do not just describe the situation of refugees in third (an observer's) person, but sometimes in first (the subject's) person too, as the poet "becomes" one of them. An example can be seen in the following excerpt, where the poem speaks of traffickers from the viewpoint of refugees in first person plural:

HOPE (poem Nr. 31, excerpt)

Noiselessly they drowned us; like the diver's last breath

We were standing in queue

For them to count us.

City animals

Had brought us next to saltiness.

All day long the azure craved for us

So fiercely that they told us - they will drown us...

But even when there are descriptions in third person, they are edgy and stir emotion:

WET GRAVE (poem Nr. 41, excerpt)

a rain of nails

crucifies dreams,

noise drowns metal sheets

in a torn inflatable boat. 
justice is

an underage refugee

without a raincoat

By contrast to refugees, Westerners in general are presented cold-hearted, indifferent and eventually maleficent towards them:

MIGRATORY BIRDS (poem Nr. 14, excerpt)

the country is sick they said

with a hemorrhagic illness

weak spring

and headache

- hospitality is a skin rash...

THROUGH THEIR BROKEN GLASS (poem Nr. 20, excerpt)

On the front pages and the news bulletins

The "mighty" give out promises.

From their broken glass,

they announce "new" measures.

Passing meaningless laws.

- What migrants and refugees, they say,

they are just signs of the time that will pass...

STEALING FROM THE DEAD (poem Nr. 57, excerpt)

Europe that has thrown

Humanity to the sea has turned

Loans of ephemeral cohabitation to a struggle for survival

That steals recklessly from

Dead

Survivors.

AMOK (poem Nr. 64, excerpt)

I find your flesh on the rails

[...]

You came last in a refugee caravan

Walls standing erect

Two steps before Heaven

Behind barriers

Innocence in the mincer. 
I find your blood on the rails

Europe of racist amok.

Poets identify themselves as Westerners and in many poems, they feel the need to apologize or to make an appeal for the unfavorable treatment of refugees:

RITSONA CAMP (poem Nr. 59, excerpt)

Fortified in our petty bourgeois living rooms ordering café latte

We zap or google or post

In which area

Can we camouflage

Human pain tomorrow.

In other instances, poems become the mouthpiece of poets who find the opportunity to castigate social stereotypes, as we also saw in Figured Worlds:

\section{MIGRANTS 2016 AD (poem Nr. 55, excerpt)}

we are of course alive but invisible

to your black glasses

that look at us but do not see us...

Ultimately, refugees are seen to have arrived to help Westerners see through the rotten foundations of their civilization:

BIRDS OF THE EAST (poem Nr. 44)

The East yesterday

Sent us its birds

Millions

They cleared the landscape

From our dead dreams.

\section{Conclusion}

This paper has looked into Greek poetry written, in its bulk, during 2014-2018, i.e. the years of the heightened European migrant crisis, for ways in which refugees and locals are presented. The 85 poems that constitute the sample of the paper were analyzed in the framework of critical discourse analysis (CDA) in terms of situated meaning, social language, intertextuality, figured worlds and discourses, i.e. along the analytical tools provided by Gee (2011). Since, however, it is social language that gives words their situated meanings in this instance, a reversal has taken place: social language was examined first and situated meaning second. 
Social language is a way of using language (choice of words, intonation, style etc.) to enact a particular socially situated identity. The social language in the poems is of course poetic language, as poets speak out their feelings and views about the situation with refugees. Contrary to everyday talk, poetic language is laden with figures of speech, such as metaphors, similes, hyperboles, irony, oxymorons, alliterations, personifications, etc. Attention was given to those figures of speech that contribute to the representations of concern. The most striking examples were written down and explained.

Situated meaning is the specific meaning situated in the context of a word's use. In the paper, situated meaning was explored within the figures of speech. This allowed symbols to be identified, as well as any added significance to certain words or phrases. Since the sample was broad, a quantitative approach was undertaken, enabling as it did the extraction of conclusions between all 85 poems in the sample. A word/notion was counted only the first time it was found in a poem, so as to prevent more "popular" words from overshadowing less used ones. Then, a threshold of at least 10 total one-time occurrences was established and a chart was produced, summing up the findings. Recurring words and/or clusters of words that were counted arithmetically in each poem were: Aegean/Mediterranean, boats, blood, children, concentration camps, death/dead, dreams, fire, food/bread, home, homeland, hope, migrants, migratory birds/migration, mother, night/darkness, pain, refugees, road, screams, sealopen sea/waves, shelter, shipwreck, sinking/drowning, sorrow, strangers, tears, water, wind. Out of them, only 18 managed to pass the threshold. The situated meaning of their most striking occurrences was then analyzed.

Intertextuality is about quotes taken from other texts or about the reference or allusion of one text into another. It may also involve instances of another social language within the same context. Children as a powerful symbol of innocence across cultures is seen to constitute such an element of intertextuality. Beyond single words and symbols, other elements of intertextuality were identified: use of parentheses, dialogue, spoken statements, rhetorical questions and phrases having an oral speech quality. These constitute examples of a different social language pervading the poems and a voice that rings higher than the general voice in the poems; one that appeals to the reader directly.

Figured worlds are a reflection of everyday theories (narratives, images, schemas, metaphors and models) about the world that inform people about what is typical or normal. Children could be such a schema. But, in the poems, refugees' children were juxtaposed to "our children" in an interesting divide that challenges the universal schema. The challenge is aptly used to underline the different circumstances, if not realities, pertaining to each group of children. The same was the case with "peace" and "sorrow". Also, the reason why some poets prefer "refugees" over "migrants" and others do not, as well as the use of "migratory birds" as a metaphor for them was also looked into.

Discourses is the total of all the previous elements; thus, they show the poets' position relevant to refugees. The sample has attested that Greek poets see in refugees a heroic part of humanity and a manifestation of the human struggle and will to live; thus, they are sanctifying them, presenting them as martyrs. Greek poets completely sympathize with them and see locals and Westerners as villains who are after their eradication. This is obviously a distorted and 
hyperbolic point of view, which however may hide true aspects of reality in its exaggeration. Various excerpts from the 85 poems of the corpus were presented, corroborating to this fact.

CDA, along Gee's analytical tools, proved a useful approach for the analysis. It allowed for a richer analytical basis, as it involves elements from sociolinguistics, cognitive psychology, literary criticism, psychological anthropology, cultural anthropology, cultural psychology and general psychology. It also allowed the social perspective to emerge from the poems, as reflected in the poets' view of the situation described in the paragraph above. This view may be hyperbolic, but nonetheless echoes the opinion of at least a part of the Greek population. Art is once again reflecting reality, even in its exaggeration, and draws attention not only to what has been happening to refugees, but to the very content of contemporary European identity.

\section{Conflict of Interest Statement}

The author declares no conflicts of interests.

\section{About the Author}

Christina Linardaki (BA English Literature from the National and Capodistrian University of Athens, MA Communications and New Journalism from the Open University of Cyprus, and Diploma in Translation by the Manchester College of Arts \& Technology) is a researcher at the Advanced Media Institute, Cyprus. She is interested in the relationship between literature and other fields of social science. She has published two research papers: "From poem and song to cultural diplomacy: Challenges and opportunities for place branding and tourism promotion" at Place Branding and Public Diplomacy, 16(4), 304-315; "The self on the wane: understatement, making-faces and \#nofilter selfies versus three autobiographical poems" at Research Journal of Language, Literature and Humanities, Vol. 7(2), 1-8.

\section{References}

Abrams, M.H. (1957/1999), A Glossary of Literary Terms, Boston: Heinle \& Heinle.

Dabic, S. (2010) “Discourse analysis versus philosophic reading of a literary text: The herne's egg, W.B. Yeats", Critical Discourse Studies, 7(2), 113-125.

van Dijk, T.A. (2015), "Critical Discourse Analysis". In: D. Tannen, H.E. Hamilton and D. Schiffrin (eds.), The Handbook of Discourse Analysis, second edition, Hoboken, New Jersey: John Wiley \& Sons, pp. 466-485.

van Dijk, T.A. (2014), "Discourse-Cognition-Society: Current state and prospects of the sociocognitive approach to discourse". In: C. Har \& P. Cap (eds.), Contemporary Studies in Critical Discourse Analysis, London: Bloomsbury, 121-146.

van Dijk, T.A. (2001), "Multi-Disciplinary CDA: A plea for diversity”. In: R. Wodak and M. Meyer (eds.), Methods of critical discourse analysis. London: SAGA Publications, 95-120. van Dijk, T.A. (1995), “Aims of Critical Discourse Analysis”, Japanese Discourse, vol. 1, 17-27. 
Fairclough, N. (2010), Critical Discourse Analysis: The Critical Study of Language, London: Longman.

Fairclough, N. (1992), Discourse and Social Change, Cambridge: Polity Press.

Fairclough, N. (1989), Language and Power, London: Longman.

Gee, J.P. (2011), How to do Discourse Analysis: A Toolkit, New York and London: Routledge.

Gee, J.P. (2004), “Discourse Analysis: What makes it Critical?”. In: R. Rogers (ed.), An Introduction to Critical Discourse Analysis in Education, Mahwah, New Jersey \& London: Lawrence Elbaum Associates, Publishers, 19-50.

Gee, J.P. (1999), An Introduction to Discourse Analysis: Theory and Method, New York and London: Routledge.

Jakobson, R. (1960), "Closing Statement: Linguistics and Poetics” in Sebeok, T.A. (ed.), Style in Language, New York: Wiley.

Mahmood, S.I. \& Majeed, M.R. (2020), "Critical Discourse Analysis of Figurative Language in the Selected Poems by Langston Hughes", 2019 International Conference on English Language and Culture, 68-73.

el-Malik, S.S. (2015), “Interruptive discourses: Leopold Senghor, African Emotion and the poetry of politics, African Identities, 13(1), 49-61.

Petracou, E., Leivaditi, N., Maris, G., Margariti, M., Tsitsaraki, P. \& Ilias, A. (2018). “Greece Country Report: Legal and Policy Framework of Migration Governance". Global Migration: Consequences and Responses - RESPOND Working Paper Series.

Wodak, R. \& Meyer, M. (eds.) (2001), Methods of Critical Discourse Analysis, London: SAGE Publications.

\section{List of poetry collections:}

Aggelopoulos, Christos (2018), Farofylakos elegies [Elegies of a lighthouse keeper], Athens: A $\Omega$.

Andrikopoulou, Niki (2016), O mov anthropos [The purple man], Athens: Gavriilides.

Chatzicharalambous, Efsevia (2018), Viographiko simeioma [Curriculum Vitae], Athens: Thraca.

Chatzopoulos, Thanassis (2012), Prosopo me ti gi [Face on earth], Athens: Gavriilides.

Chloptsioudis, Dimos (2016), Akatallilo [NC-17], Athens: Mandragoras.

Chouliaras, Giorgos (2005), Dromoi tis melanis [Roads of ink], Athens: Nepheli.

Dimitriadou-Efraimidou, Eleni (2014), Doriis ke xylokopoi [Dorians and woodcutters], Athens: Gavriilides.

Dimouli, Aggeliki (2015), Ta eterofota [The hetero-lighted], Athens: Vakxikon.

Filis, Tellos (2018), To eschato erma [The ultimate ballast], Athens: Polis.

Frangos, Giorgos (2018), Floisvos synefon [Roaring of clouds], Athens: Vakxikon.

Ganelis, Giorgos (2017), Ypo to miden [Below zero], Athens: Stochastis.

Kaimaklioti, Aggela (2014, Ek tou syneggys [From up close], Athens: Farfoulas.

Kaitatzi-Choulioumi, Despina (2017), Ligostevoun i lexis [Words grow less], Athens: Melani.

Karakokkinos, Andreas (2017), Lathrepivates se peiratiko [Stowaways on a pirate ship], Thessaloniki: Eneken. 
Kolossiatou, Frosoula (2017), Foraei ta matia tou nerou [He wears the eyes of water], Athens: Gavriilides.

Kolossiatou, Frosoula (2014), Skoteini Sygkatoikisi [Dark cohabitation], Athens: Gavriilides.

Konstantopoulou, Niki (2014), Apopse niotho mia dropi [Tonight I feel shame], Athens: Peri technon.

Kopsida-Vrettou, Vivi (2018), Chirapsies mias asimantis meras [Handshakes in a meaningless day], Athens: Vakxikon.

Koutsoumbeli, Chloe (2016), Oi omotrapezoi tis allis gis [The messmates of another land], Athens: Gavriilides.

Koutsoumbeli, Chloe (2009), I alepou kai o Kokkinos horos [The fox and the red dance], Athens: Gavriilides.

Latsari, Maria (2016), En dynamei pragmatikotita [Potential reality], Athens: Mandragoras. Liatzoura Katerina (2017), Apokaidia ithikis [Cinders of ethics], Athens: Vakxikon.

Lountzis, Alekos (2015), Propaganda, Athens: Gavriilidis.

Mendrinou, Nektaria (2018), Synefa sto nero [Clouds in water], Athens: Melani.

Naoum, Chara (2013), Agrypnes antilopes [Sleepless antilopes], Athens: Mandragoras.

Nikitas, Zafeiris (2015), Ta nera tou metanasti [The immigrant's waters], Athens: Melani.

Papadopoulos, Michail (2016), Anthro peino [Hunger for man/Humane], Athens: Mandragoras.

Politou, Maria (2018), Epitelous Apovivasi [Debarkation at last], Athens: Koukkida.

Sakalis, Grigoris (2015), Kytio kryfon oneiron [Box of hidden dreams), Athens: Endymion.

Sidira, Aggeliki (2016), Silver alert, Athens: Kedros.

Silfitzoglou, Kyriakos (2014), Me ifos Indianou [In the style of an American Indian], Athens: Melani. Siotis, Dinos (2004), Den xero, den apanto [I don't know, I don't answer], Athens: Kedros. Skouroliakou, Maria (2015), Chroma avrio [Color tomorrow], Lamia: Lamiakos Typos. Skouroliakou, Maria (2008), Akathistos logos [Unseated uttering], Lamia: Lamiakos Typos. Stamboglis, Stavros (2014), Dialektiki vythou [Bottom of sea dialectics], Athens: Mandragoras. Tetrazis, Fileas (2017), Den ine omos etsi [But it is not so], Athens: Polaris.

Toumanidis, Christos (2014), I elegies tis Anatolis [The elegies of the East], Athens: Koukkida. Vakirli, Polyxeni (2015), Mikro aloni [Small threshing floor\}, Athens: Gavriilides.

Verouchis, Antonis (2015), Ta chronia tis krisis [The years of the crisis], Athens: Vakxikon. Xirogianni, Asimina (2013), Epochi mou ine i piisi [My time is poetry], Athens: Gavriilides. 

to their work. Under the terms of this license, no permission is required from the author(s) or publisher for members of the community to copy, distribute, transmit or adapt the article content, providing a proper, prominent and unambiguous attribution to the authors in a manner that makes clear that the materials are being reused under permission of a Creative Commons License. Views, opinions and conclusions expressed in this research article are views, opinions and conclusions of the author(s). and European Journal of Literature, Language and Linguistics Studies shall not be responsible or answerable for any loss, damage or liability caused in relation to/arising out of conflicts of interest, copyright violations and inappropriate or inaccurate use of any kind content related or integrated into the research work. All the published works are meeting the Open Access Publishing requirements and can be freely accessed, shared, modified, distributed and used in educational, commercial and non-commercial purposes under a Creative Commons Attribution 4.0 International License (CC BY 4.0). 